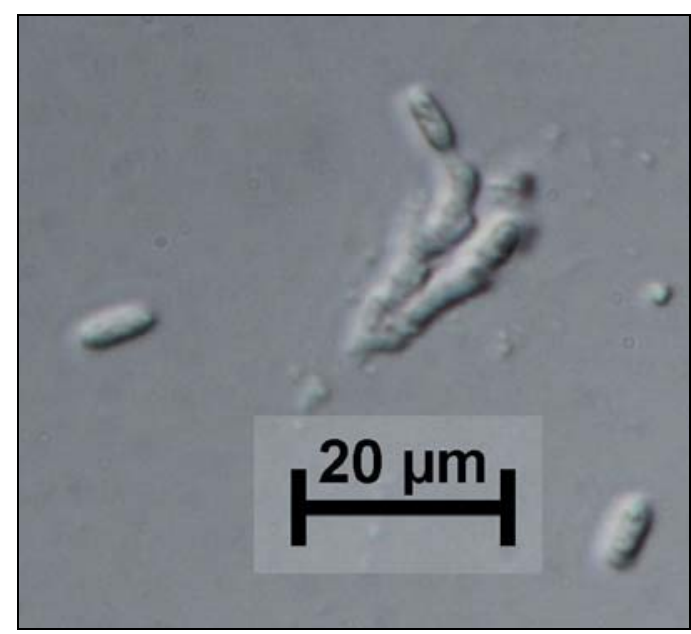

Slika 3: Trosonosci s konidiji glive Meria laricis

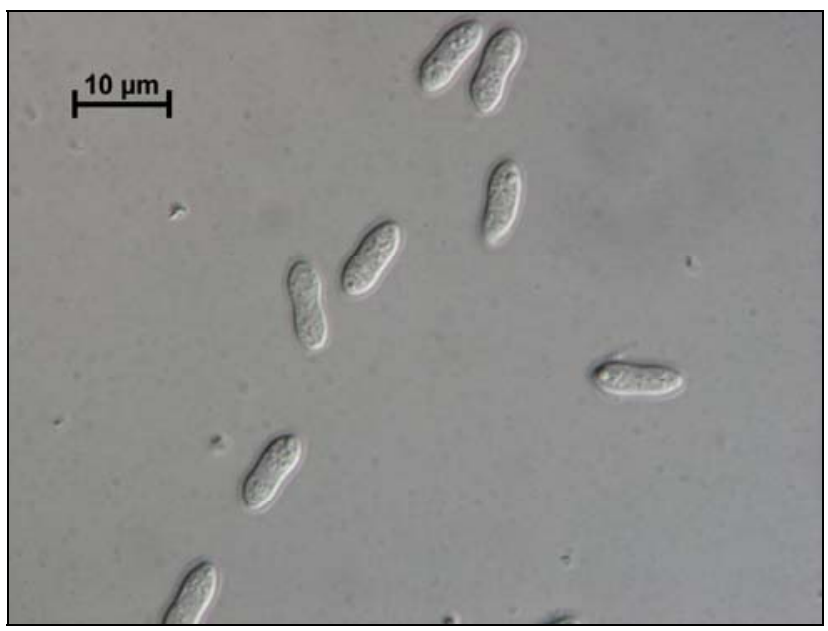

Slika 4: Brezbarvni konidiji glive Meria laricis

\title{
Vzroki izredno obsežnega pojava sušice najmlajših borovih poganjkov (Diplodia pinea) v okolici Podgorja leta 2008
}

\section{Nikica OGRIS $^{1^{*}}$, Boštjan KOŠIČEK ${ }^{2}$}

$\mathrm{Na}$ širšem območju Slavnika se je v letu 2008, na več sto hektarih gozda, pojavila sušica najmlajših borovih poganjkov na črnem boru (slika 1). Jakost bolezni je bila tako drastična, da se niso sušili samo najmlajši poganjki, ampak tudi veje in cela drevesa (slika 2). Zanimivo je prav to, da je bilo sušenje letošnjih ali lanskih poganjkov (slika 3) prej izjema kot pravilo, saj so v večini primerov odmrle cele veje in cela drevesa. Sušico najmlajših borovih poganjkov povzroča gliva Diplodia pinea (Desm.) J. Kickx f. (sinonim Sphaeropsis sapinea (Fr.) Dyko \& B. Sutton). Vsako leto povzroča na Krasu in drugod po Sloveniji večje ali manjše škode na borih. Raziskali smo domnevne vzroke, zakaj je v letu 2008 v Podgorju na Krasu povzročila tako veliko škodo.

Sušica najmlajših borovih poganjkov je dobro raziskana bolezen borov. Gliva Diplodia pinea je endofit, ki biva $\mathrm{v}$ zdravem tkivu in $\mathrm{v}$ normalnih okoliščinah borom ne povzroča nobene škode (Stanosz in sod., 1997) vendar postane patogena, kadar je rastlina v stresu. Diplodia pinea postane patogena v sušnem stresu (Stanosz in sod., 2001), po poškodbah zaradi toče (Smith in sod., 2002), po napadu žuželk (Feci in sod., 2003), ali pri pomanjkanju hranil. Večje poškodbe zaradi sušice najmlajših borovih poganjkov so zabeležili tudi v zaprtih dolinah ali zaprtih sestojih, kjer je višja relativna zračna vlažnost in so nihanja $v$ temperaturi zraka manjša (Zwolinski in sod., 1990). Črni bor (Pinus nigra Arn.) je načeloma odporen proti poletni suši in visokim temperaturam, ki se velikokrat pojavlja v mediteranskem območju. Vendar je zelo občutljiv na sušo $\mathrm{v}$ spomladanskih mesecih in na hitre spremembe temperature $\mathrm{v}$ času zime (Jankovsky in Palovčíková, 2003).

Povprečna letna količina padavin v obdobju 19712000 na območju Podgorja je bila 1552 mm. Najbližja padavinska postaja je Rakitovec, ki je od Podgorja oddaljena približno $6 \mathrm{~km}$. Iz slike 4 vidimo, da je bila povprečna letna količina padavin $\mathrm{v}$ Rakitovcu v obdobju 2000-2008 vsa leta podpovprečna z največjim primanjkljajem v letu 2003 in 2007 (ARSO, 2009). V letu 2007 je padlo $22 \%$ manj padavin kot povprečno. Iz podrobne analize količine padavin smo ugotovili, da je v letu 2007, eno leto pred obsežnim sušenjem črnega bora pri Podgorju, bistveno primanjkovalo padavin pomladi in poleti, v mesecih, ko je črni bor najbolj občutljiv na pomanjkanje padavin. Zima 2007/08 je bila nadpovprečno topla. Glede na podatke iz postaje Godnje je bila temperatura za $1,9{ }^{\circ} \mathrm{C}$ višja kot znaša dolgoletno povprečje. Povprečna letna temperatura pa je povprečje presegla za $2,0^{\circ} \mathrm{C}$, kar je enako kot leta 2003, ko je v Sloveniji pustošila suša. Pomlad 2007 je bila še posebej topla, saj je presegala dolgoletno povprečje za $3,3^{\circ} \mathrm{C}$. Predvsem nadpovprečno topla zima in pomlad v letu 2007 skupaj s pomanjkanjem padavin $\mathrm{v}$ istem času, so bili verjetno kritični za črni bor pri Podgorju. Menimo, da so prav takšne razmere pomenile zelo velik stres za črni bor in ga tako predisponirale za sušico najmlajših borovih poganjkov. Poleg tega so na postaji Rakitovec 30. aprila 2007 zabeležili točo, na postaji Podgrad pa še dve večji toči 23. maja 2007 in 27. septembra 2007. Toča je bila še dodatni stresni dejavnik, ki je na vejah in vejicah pustila poškodbe, t. j. odprte rane, katere je Diplodia pinea lažje okužila. Mikroklimatske razmere pri Podgorju ustrezajo zaprti dolini, ki jo z vseh strani obkrožajo višji hribi: Slavnik, Kojnik in Velike gorice. Vse naštete vremenske razmere (višje temperature, pomanjkanje padavin, toča) in orografske lastnosti pri Podgorju dovolj dobro pojasnjujejo izredno obsežne poškodbe zaradi glive Diplodia pinea v letu 2008 pri Podgorju. 


\section{Viri}

ARSO. 2009. Podatki o dnevni količini padavin na padavinski postaji Rakitovec in o dnevnih temperaturah na klimatološki postaji Godnje: podatkovna zbirka. Agencija RS za okolje

Feci E., Smith D., Stanosz G.R. 2003. Association of Sphaeropsis sapinea with insect-damaged red pine shoots and cones. Forest Pathology, 33: 7-13

Jankovský L., Palovčíková D. 2003. Dieback of Austrian pine - the epidemic occurrence of Sphaeropsis sapinea in southern Moravia. Journal of forest science, 49, 8: 389-394

Smith H., Wingfield M.J., Coutinho T.A. 2002. The role of latent Sphaeropsis sapinea infections in post-hail associated die-back of Pinus patula. Forest Ecology and Management, 164: 177-184

Stanosz G.R., Smith D.R., Guthmiller M.A., Stanosz J.C. 1997. Persistance of Sphaeropsis sapinea on or in asymptomatic shoots of red and jack pines. Mycologia, 89, 4: 525-530
Stanosz G.R., Blodgett J.T., Smith D.R., Kruger E.L. 2001. Water stress and Sphaeropsis sapinea as a latent pathogen of red pine seedlings. New Phytologist, 149: 531-538

Zwolinski J.B., Swart W.J., Wingfield M.J. 1990. Intensity of dieback induced by Sphaeropsis sapinea in relation to site conditions. Forest Pathology, 20: 164-174

${ }^{1}$ Gozdarski inštitut Slovenije, Večna pot 2, 1000 Ljubljana; ${ }^{2 Z a v o d ~ z a ~ g o z d o-~}$ ve Slovenije, Območna enota Sežana, Partizanska 49, 6210 Sežana *nikica.ogris@gozdis.si

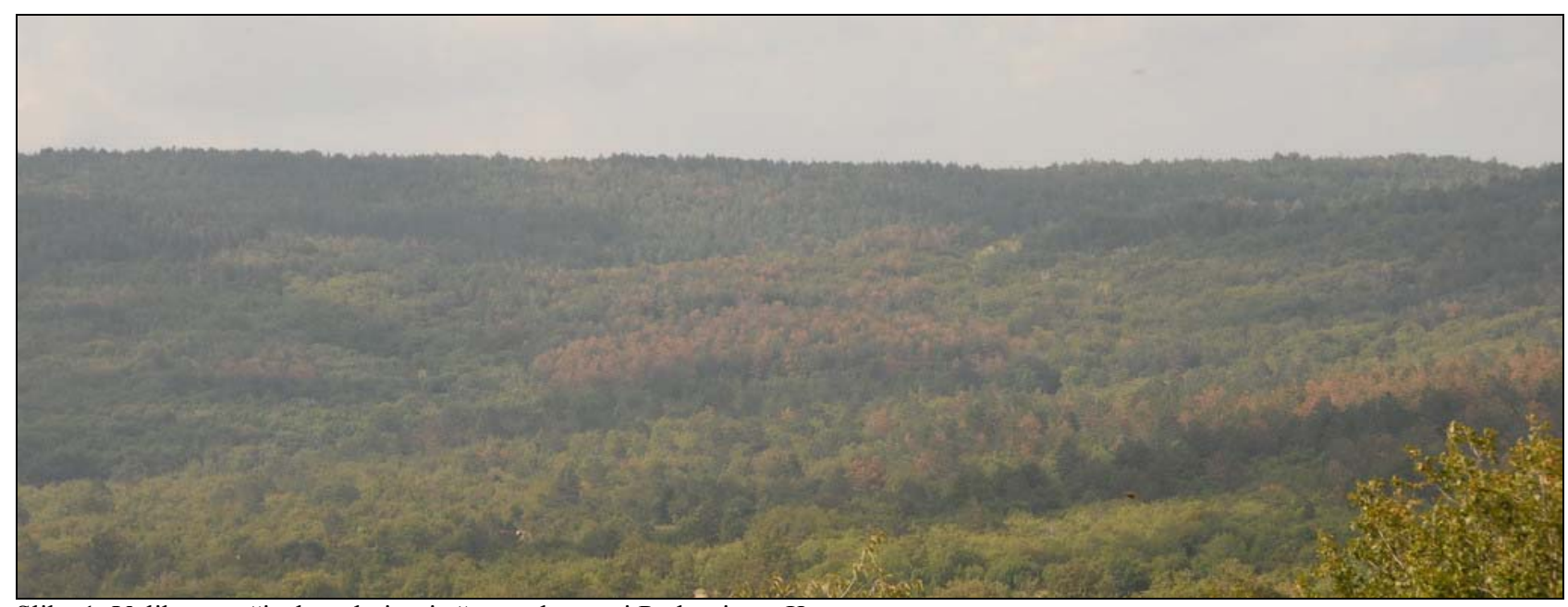

Slika 1: Veliko površinsko odmiranje črnega bora pri Podgorju na Krasu

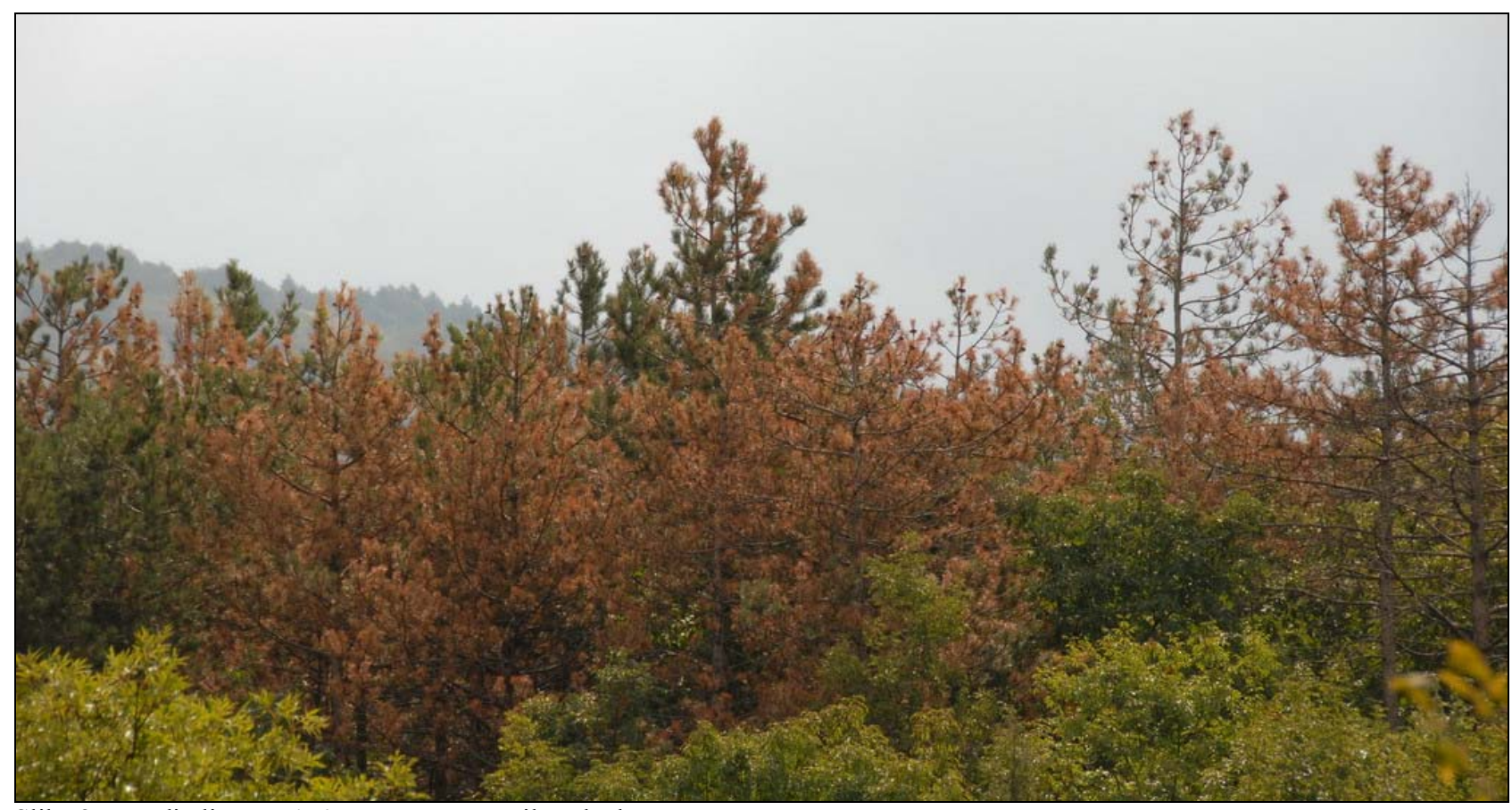

Slika 2: Zaradi glive Diplodia pinea so se sušila cela drevesa 


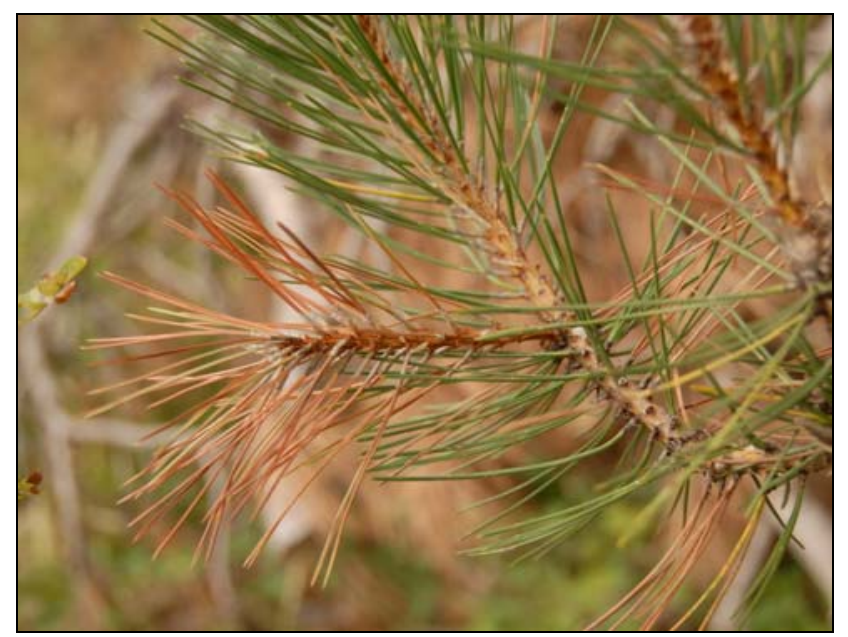

Slika 3: Ne tipičen simptom, ki ga je povzročila gliva Diplodia pinea na območju Podgorja na Krasu v letu 2008 - odmiranje najmlajših borovih poganjkov z dokončno zraslimi iglicami (pri tej bolezni navadno iglice niso dokončno zrasle)

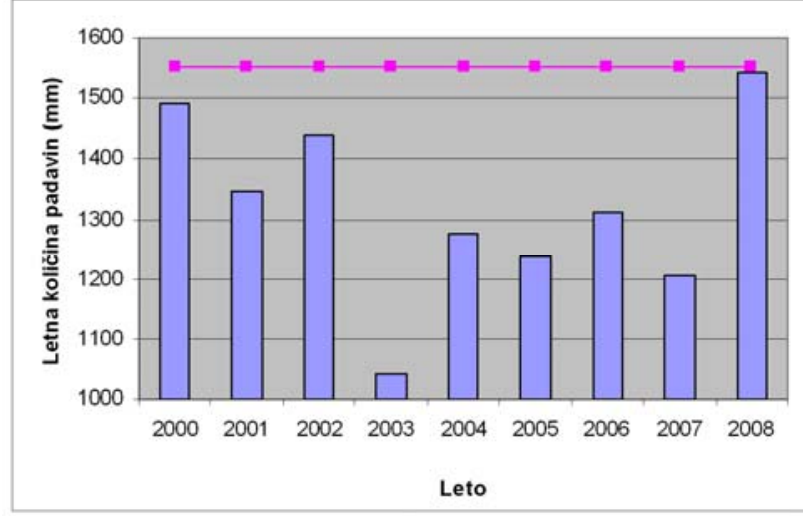

Slika 4: Povprečne letne količine padavin na padavinski postaji Rakitovec 2000-2008 (ARSO, 2009)

\section{Veverice so pogrizle smrekove brste in naredile preprogo iz smrekovih vejic na Pohorju v zimi 2008/09}

\section{Nikica OGRIS $^{1^{*}}$, Nenad ZAGORAC ${ }^{2}$}

Spomladi 2009 smo na širšem območju Hočkega Pohorja opazili nenavadne poškodbe navadne smreke (Picea abies (L.) Karst.): ogromno število vejic dolžine ok. $10 \mathrm{~cm}$ je ležalo pod smrekami, kot da bi bile odrezane z ostrim nožem ali škarjami (slika 1); včasih je bilo vejic toliko, da jih je bilo za več $\mathrm{cm}$ na debelo (slika 2); vse vejice so bile brez popkov, kot da jih je nekdo pojedel.

Povzročitelj za takšno vrsto poškodbe je že zelo dolgo znan (npr. Hosley, 1928). Takšne poškodbe povzroča navadna veverica (Sciurus vulgaris L.). Znano je, da se navadna veverica prehranjuje poleg orehov, semeni, jagod, gob skorje, žuželk, ptičjimi jajci, goliči tudi s popki in poganjki (Jurc, 2008). Navadna veverica popke poje tako, da prej odgrizne vejico in potem $\mathrm{z}$ nje obere popke. Poleg navadne smreke povzroča podobne poškodbe še na rdečem boru (Pinus sylvestris L.) in navadnem macesnu (Larix decidua Mill.). Poškodbe se zgodijo takrat, ko veverice ne morejo pri do hrane na tleh - do zalog, ki so si jih pripravile poleti in jeseni, to se zgodi navadno $\mathrm{v}$ zimah $\mathrm{z}$ debelejšo snežno odejo. Količina poškodb je odvisna tudi od velikosti populacije navadne veverice. Populacija navadne veverice je večja v smrekovem debeljaku, saj ta nudi z več storži več hrane (Andrén in Lemnell, 1992). V primeru debele snežne odeje $\mathrm{v}$ smrekovem debeljaku bo več veveric lačnih in zato bo posledično več poškodb na poganjkih z obžiranjem popkov. Z raziskavo so ugotovili, da je gostota populacije veverice odvisna tudi od količine storžev, ta pa je odvisna od količine padavin v prejšnjem letu (Kemp in Keith, 1970; Andrén in Lemnell, 1992).

Izguba večjega števila poganjkov navadni smreki ne predstavlja dolgotrajnih poškodb. Ukrepov proti tej vrsti poškodb ne poznamo. Obstaja možnost, da navadni veverici ob pomanjkanju hrane, npr. $\mathrm{v}$ zimi z debelo snežno odejo ali kadar je bil obrod storžev premajhen za prehranske zmožnosti večje populacije veveric, nudimo krmo, kot so lešniki in orehi.

\section{Viri}

Andrén H., Lemnell P.-A. 1992. Population fluctuations and habitat selection in the Eurasian red squirrel Sciurus vulgaris. Ecography, 15, 3: 303-307

Hosley N.W. 1928. Red squirrel damage to coniferous plantations and its relation to changing food habits. Ecology, 9, 1: 43-48

Jurc M. 2008. Gozdna zoologija. Ljubljana, Univerza v Ljubljani, Biotehniška fakulteta, Oddelek za gozdarstvo in obnovljive gozdne vire: 348 str.

Kemp G.A., Keith L.B. 1970. Dynamics and regulation of red squirrel (Tamiasciurus hudsonicus) populations. Ecology, 51, 5: 763-779

${ }^{1}$ Gozdarski inštitut Slovenije, Večna pot 2, 1000 Ljubljana; 2Zavod za gozdove Slovenije, Območna enota Maribor, Tyrševa 15, 2000 Maribor *nikica.ogris@gozdis.si 